\title{
Analysis of Reading Material and Students' Perception Towards Buku Bahasa Inggris at Grade X Semester II of SMAN 4 Payakumbuh
}

\author{
Elsa Sastrawati ${ }^{1, *}$ Hermawati Syarif ${ }^{1}$ Muhammad Al Hafizh ${ }^{1}$ \\ ${ }^{1}$ Universitas Negeri Padang, Sumatera Barat, Indonesia \\ *Corresponding author. Email: echa.sastra@gmail.com
}

\begin{abstract}
The aim of this research is to describe how are reading materials in Buku Bahasa Inggris in aspect texts and task viewed from teachers' and researcher's perception and also the perception of the students toward this reading materials in this students' textbook. The main source of teaching materials comes from textbook. This research analyzes reading materials in students' English textbook of 2013 curriculum for grade X semester II. Source of the data in this research is divided into two. First is analysis checklist of reading materials in the students' English textbook of 2013 curriculum for grade X semester II filled by three analysts? Two analysts are English teachers at SMAN 4 Payakumbuh and the other one is researcher herself. The checklist includes two indicators of reading material that are texts and tasks of reading materials. Second is the questionnaire of students' perception toward reading materials. After all the collected, it found that the reading texts in this textbook have fulfilled the criteria. The aspects are interest, authenticity, cultural background knowledge, layout, visual, and value. On the other hand, the lexical knowledge in the reading text is not suitable with the students' level. There are too many unfamiliar words found in each reading text. Then, the reading tasks in the students' English textbook do not provide variety of questions in the task. There was not any question that reflected guessing meaning from the context. Last, the students viewed that the reading text are too long and many difficult words that make them cannot understand the text well and hard to answer the questions in reading tasks.
\end{abstract}

Keywords: reading material, perception, reading text, reading task

\section{INTRODUCTION}

Teaching material is one of the important aspects in teaching and learning process. Material as part of curriculum is the reason why it becomes an important aspect in teaching and learning process. Then, material as source of knowledge are developed to help teachers facilitate students' prior knowledge, assist them to process and understand the new learning and eventually aid them apply newly acquired knowledge to their practical lives. Additionally, material as a tool to obtain the competency that supports learning content, allows students to engage their concept application and provide opportunity for evaluation.

Due to the important of materials, the government provides the teaching materials include curriculum 2013. This is intended to make the students be aware of the functions of reading in their life. One of reading sources that is used in teaching and learning process is textbook. Textbook consists of instructional materials. It provides many information and knowledge. It is used by the teacher and students in the learning and teaching process as a main source. McGranth [1] states that the textbook must meet the need of teaching syllabus and curriculum. It means the content of the textbook has to be able to fulfill the need of curriculum or syllabus used. In other word, the textbook consist of teaching materials which help the students to achieve the competences that are demanded by curriculum and syllabus used.

In curriculum 2013, genre of texts is offered as reading functional texts and monologues texts. Through reading materials, the students can also learn new vocabulary and culture. While they are learning, they can also experience the language in the real world beyond the classroom. The use of reading materials can be influenced by the perceptions of teachers and students because they are the main users. Perception of teachers and students of reading materials that have been used aims to determine the extent of teachers and students needs of the reading material itself, so that the reading materials can be an effective resource in getting the knowledge. Perception is a process of understanding what is experienced. According to 
Suharman [2] perception is a process of using knowledge that has been processed and stored in memory to detect or obtain and interpret stimuli that received by sense.

English teaching materials used by the teachers come from many sources. However, the main source used by the teachers is the teaching materials from textbook. Moreover, the textbook used by the English teachers right now is "Buku Bahasa Inggris" published by the Minister of Education and Culture and it is designed by the experts chosen by the government. It is supposed that the textbook is good to be used. The textbook consists of several materials to cover all skills to support the teacher and students in teaching and learning process. This research focuses on reading materials in aspect of reading texts and tasks.

Reading materials are the essential elements in teaching learning process because they are vehicle to run the teaching learning process. Chingos and Whitehurst [3] states that reading materials are important, so appropriate materials will give good outcomes. Teachers give appropriate materials for appropriate level of students. In other words, materials provide techniques and exercises that are used in teaching learning process. They do not only provide the topic of the lesson but also include teaching techniques, exercises even they can be explored into learning activities in order to reach the goal of learning. In short, Thomlinson [4] states reading material refers to any texts passage that brings certain message or ideas to be shared to the reader through the process of reading activity. Students who are good in reading will get some gains related to their success at school. Therefore in preparing the materials, there are some criteria should be involved in reading materials and the reading material should involve some main skills in reading.

The reading text should fulfill the criteria of good reading text as follows: First, interest is the most important factor in selecting text. It increases motivation that will make students read more as stated by Hidi, Renninger \& Krapp [5] that interest is a motivational variable that involves not only the emotions but also the intellect, making it a powerful energizer indeed. The more the students read, the better a reader will become, not only improving their language level but also confidence. Second is lexical knowledge. Vocabulary is also important part in reading. The relationship between vocabulary and reading comprehension is complex and dynamic. Without sufficient vocabulary, readers may make a wild guess at the unknown words, and may not be able to fully understand the reading texts. Hu and Nation [6] stated that lexical knowledge is one of the most important elements that determine the text readability. Third, authenticity of the text will bring students close to the target language culture, making learning more enjoyable and therefore more motivating. Through the authentic materials provided, students can explore a wider range of topics and situations in the target language, with the accompanying linguistic elements, than may be available to them in their course books.

Cultural background knowledge is an essential factor that affects comprehension. The texts that are not related to the students' culture and religion will be less motivating for them to read and will be more difficult to comprehend than the culturally-related ones. Fifth is text layout. Many factors affect the legibility of a reading text. Among those are font types, font size, the size of spaces between words, lines, or paragraphs, the width of margins, the nature of ink used for printing and the texture, colour and reflective of the paper. Sixth, text visual also takes an important part in reading text. Jahangard [7] defines visual materials as the facilities that can enhance language learning in the classroom. Pictures and other visual materials can activate students' prior knowledge. Students usually react more favorable to bright, colourful, interesting and well-illustrated material. Last, text value is a belief which need not rely upon facts or evidence, although a value position can be supported or challenged by knowledge propositions. Values represent the third basic component of a syllabus.

The reading task should fulfill the criteria of good reading task as follows: First, variety Variety means to use different kind of questions that cover all the skills. This may be covered by open questions, multiple-choice questions, right or wrong questions, etc. The textbook should include exercises that give students opportunities to practice and extend their reading skills. Second, purity of reading exercises means that the answer of these exercises depends mainly on reading and comprehension. The pure reading exercise measure how much students understand from the reading text. They do not take into consideration other language skills; writing, listening and speaking or language aspects; pronunciation, grammar, spelling and vocabulary. Last is coverage of the reading skills. It means, reading tasks should cover all the skills that curriculum aims at. According to Nation [8] there are some forms of questions that can be used in tasks when the teachers want to measure the reading achievement of the students.

Based on the preliminary data gotten from informal interview with some English teachers at school, the teachers seem not perceive the textbook well. They said that some of the materials especially the reading materials are not suitable with the students' level. Most of the texts in the textbook contain too many unfamiliar words that make the students difficult to understand the text. Then, when teacher asked something about the text they have read, only few of them could answer it. In line with the interview with some students at SMAN 4 Payakumbuh, they said that the texts are difficult, long and many difficult words that they do not understand the meaning so that they cannot comprehend the text well. 


\section{METHOD}

This research belongs to descriptive research. By using this type, the researcher gathered information about teachers' and students' opinion and analyzed the reading materials in students' textbook used in teaching reading in the classroom. In this research the researcher described about teachers' and students' perception of the used reading materials in teaching English, especially in reading comprehension.

The data of this research are the reading materials in students' textbook entitled "Buku Bahasa Inggris" for grade X. The sources of the data in this research will be the researcher and students in SMAN 4 Payakumbuh academic year 2019/2020 grade X. The data were collected from analysts related to reading texts by using analysis checklist. The indicators in analyzing the reading texts were elaborated into several sub-indicators for each of them. Then, the questionnaire was used to collect the information from students regarding their perception about reading materials in students' textbook. Then, the textbook that used by the English teachers will be also used as the source of data in this research.

\section{Findings and Discussion}

The suitability of reading texts with the good criteria of reading materials in students' English textbook for senior high school grade $X$

1. Interest

In this aspect found that most of the texts of reading materials in the textbook were judged as interesting texts. Four from five texts were included into interesting text by the analysts. Interesting texts can make students interested to read the text. The interesting text can be seen from the text topic. For example, text about meet the idol that is provided in chapter 1 of the book is based on the fact that happened in the society. The students will interest with the text because it relates with their life.

\section{Lexical knowledge}

The lexical knowledge in this research was seen from three aspects. Two aspects related to the vocabulary and the other is related to the sentences difficulty. From those aspects, it was found that most of the texts of the reading materials include so many unfamiliar words in the texts. Every text consists of words, phrases, clauses, sentences, and paragraphs. Each of components is related to each other. In addition, this research limit evaluating the lexical knowledge of the text based on the words and sentences. From the word, it is seen from the unfamiliar words found in the text, and whether the words have lexical meaning or not. Meanwhile from the sentences, it is seen from the sentence difficulty whether it is suitable with the students' level.

\section{Authenticity}

There are two aspects in this research that are seen in analyzing the authenticity of a text. They are the text is up- to-date and the text is realistic. The authenticity of a text is important to be considered in deciding a text that will be given to the students. The authenticity of a text can be seen from some aspect. From two aspects, it was found that most of the texts in reading materials are authentic.

\section{Cultural background knowledge}

Cultural background knowledge was seen from the suitability with the students' cultural background knowledge. Culture is the context within which we exist, think, feel and relate others. Considering the cultural background knowledge of the students' background knowledge of the students' is crucial since it will affect the students' comprehension and appreciation of the texts. Topics that are familiar in one culture may not be accepted in another. From the data gathered, it was found that there were three texts that are suitable with the students' cultural background knowledge.

\section{Text layout}

Text layout of a text is important. A text that has good layout will attract students' attention to read the text. To evaluate the text layout, there are several aspects that are used to see the text layout in this research. They are the font size, the spaces between words, paragraphs, and the color. From the data gotten, all of the texts were judged have good layout by the analysts. All of reading texts has good organization and have interesting color. Each of the text has different color as the background of the text. It can motivate students to read.

\section{Text visual}

Text visual and layout are two things that support the text appearance. Text visual can also help students in understanding the text. The text visual can be in form of picture, diagrams, charts and model.

Based on the data, all of the texts of reading materials in students' textbook provide visual in a form of picture. The visual is suitable with the content. They are clear and also attractive.

\section{Text value}

The last aspect in analyzing the reading material in term of reading text is the text values. Considering the values of the text given to the students is crucial. It is known that, nowadays the educational goals are not only focus on the cognitive only but also the affective and the psychomotor. Moreover, it also happens in our country, one of the reasons of the changes of the latest curriculum with 2013 curriculum is the unbalanced among cognitive, affective and psychomotor. 2013 gives more attention to the figuration of students' character besides the cognitive and psychomotor. It means, the materials contain values in it. In order to from the students' attitude or character, the value in a text is important. The analysts found that all of the texts in each chapter provide values both social and moral values. 


\section{The suitability of reading task with the good criteria of reading materials in students' English textbook for senior high school grade $X$}

1. Variety in Reading Exercises

Variety in reading exercises was seen from questions in the tasks include several kinds of questions like WH-questions, multiple choice, factual questions, thinking and guessing questions, etc. Moreover, based on the data gotten, most the tasks of the reading materials are in WH-questions. The same kinds of questions are repeated in each chapter except in chapter 4 . It means that the questions of the tasks are not varied.

2. Purity of Reading Exercises

This aspect was seen trough the questions which ask students to answer questions that the answer is explicitly stated in the text. Furthermore, based on the data gathered, the tasks in chapter 1, 2, 3 and 5 include purity of reading exercises judged by the analysts. On the other hand, the other two tasks do not include purity of reading exercises.

3. Coverage of Reading Skill

The last aspect in analyzing the reading material in term of tasks of the reading material is coverage of reading skills. In addition, there are five reading skill that should be included in the questions of the tasks in this research. They are skimming, scanning, guessing meaning from context, making inference and summarizing. Based on the data gotten, the questions only cover the reading skill in form of skimming, scanning and summarizing while the other two skills that making inference and guessing meaning from context are not found in the questions.

\section{CONCLUSION}

Based on the result analysis that has been described, it can be conclude; first is regarding to the aspect of good criteria of reading text; interest, lexical knowledge, authenticity, cultural background knowledge, text layout, text visual and text values, reading text in English textbook have fulfilled the citeria. Lexical knowledge in the reading text is not suitable with the students' level. There are too many unfamiliar word found in each reading text. Second, the reading tasks in students' English textbook do not provide variety of questions in the tasks. The same kinds of questions were repeated in all chapters. The task included questions that are used to know the students' comprehension of the texts. However, there was not any question that reflected guessing meaning from the context whereas that reading skill is often appears in the examination. In conclusion, it can be asserted that the reading materials presented in "Buku Bahasa Inggris" met some of the criteria of good reading text and reading task.

\section{REFERENCES}

[1] I. McGrath, Materials evaluation and design for language teaching, 2nd ed. Edinburgh, Scotland: Edinburgh University Press, 2016.

[2] Suharman, Psikologi Kognitif. Surabaya: Srikandi, 2005 .

[3] Chingos, M. M \& Whitehurst, G. J. Choosing Blindly Instructional Materials, Teacher Effectiveness and the Common Core. Brookings. (2012)

[4] Thomlinson, B. Developing materials for language teaching. British: Bloomsbury publishing plc. (2013)

[5] S. Hidi, K. A. Renninger, and A. Krapp, "Interest, A Motivational Variable That Combines Affective And Cognitive Functioning," in Motivation, Emotion, And Cognition: Integrative Perspectives On Intellectual Functioning And Development, D. Y. Dai and R. J. Sternberg, Eds. Mahwah, NJ: Lawrence Erlbaum Associates, 2004, pp. 89-118.

[6] M. Hu and I. Nation, "Unknown vocabulary density and reading comprehension," 2020.

[7] Jahangard, A. The evaluation of the EFL materials taught at Iranian public high schools. Asian EFL Journal, 1, 130-150. (2007). http://www.asian-efl-journal.com/

[8] Nation, I. S. P. Teaching ESL/EFL Reading and Writing. Madison Ave, New York: Routledge. (2009) 